\title{
J. N. "Ding" Darling: The Formative Years*
}

\author{
David L. LendT
}

"Ding" Darling was the popular cartoonist for the Des Moines Register from 1906 until his retirement in 1949, except for a brief career at the New York Globe. He also drew cartoons from 1900 until 1906 for the Sioux City Journal. In his nearly fifty years of cartooning, Darling saw profound changes in his surroundings and he won two Pulitzer prizes for his skillful interpretations of national and international events. At the zenith of his career, in the early thirties, "Ding" was recognized as the finest editorial cartoonist in the nation. His work was syndicated, through the New York Herald Tribune, to more than 130 newspapers and millions of daily readers.

Darling, however, enjoyed two successful careers. He was devoted to the intelligent stewardship of natural resources long before conservation and ecological considerations were fashionable. He helped create the lowa Conservation Commission and to shield it from political interference. He instigated a biological survey of the state and created the bench-mark Twenty-fiveYear Plan in Iowa that became the conservation planning model for other states. Darling went to Washington, D.C., to head the

*This excerpt is Chapter 1 from the book Ding: The Life of Jay Norwood Darling, Copyright 1979, David L. Lendt, Ames, The Iowa State University Press. Reprinted by permission of author and publisher. 
Biological Survey-forerunner of the Fish and Wildlife Service -during the New Deal. He was the prime mover in the creation of the national wildlife refuge system and in the organization of the huge National Wildlife Federation. His early life, spent on the brink of the western frontier, contributed to the philosophy he maintained until his death in 1962. The following article concerns Darling's childhood years and the beginnings of his devotion to conservation.

\section{J AY NORWOOD DARLING was born October 21, 1876.} Thirty-five years later he was so famous the New York Globe facetiously suggested that "the Centennial at Philadelphia was laid down in the year 1876 in order to coincide with the birth of J.N.D." ${ }^{11}$ Darling took his middle name from his birthplaceNorwood, Michigan, on Grand Traverse Bay. It was a remote and primitive area forty miles from any rail line, shut in each winter by heavy snows and vicious cold. Jay's father, a former schoolteacher and principal who had turned suddenly to preaching the gospel, had been sent to Norwood by the Michigan Methodist Conference.

The conference was to pay the Reverend Marcellus W. Darling and his wife $\$ 500$ per year and provide a house for them and their son Frank Woolson Darling. In fact, the family received $\$ 69$ in local scrip, and the remainder of the monetary obligation was satisfied with provisions "gladly and freely" shared by members of the congregation.

Marc Darling had enjoyed some success as a student, a professor, and an educational administrator before "politics" saw him fired from a responsible position. A native of Cattaraugus County, New York, Jay's father was born in 1844 in a onestory, unpainted frame house. He was the eighth of eleven children. One of his brothers died in 1850, another in 1851. Young Marc nearly died of scarlet fever.

Marc Darling's most memorable childhood experience, one

\footnotetext{
'New York Globe, Clipping, 1911, Scrapbook 2, Darling Papers, The University of Iowa Library. Hereafter cited as DP.
} 


\section{J. N. "Ding" Darling}

with mystic and religious overtones, occurred about the time his two brothers died. He described the experience more than a half-century later:

My mother was sitting by the window, meditating, as was her habit, in silence, when somehow by question and answer between us, there came into my mind the sense of God's presence in my soul. A sense so real and so living that it has never left me, now after more than 56 years. I carried it with me throughout all these years, in doubt at times of many other things, in distress, in battle, in college, in all my experiences.

Darling described his mother as pious, even though she rarely spoke of religion. Diantha Groves Darling was quiet, meditative, and reserved but she wielded great influence over her children. Timothy Darling, Marc's father, was as hot-tempered as he was tenderly affectionate. The large family had difficulty making ends meet on their small farm, and Tim Darling's mercurial personality made poverty no more bearable. The Darlings wore home-sheared, homespun, and homemade clothing. Although Marc could not remember going hungry, he knew "we often came very near to it."

Marc was a dreamer in a time and place where hard work and long hours, in the Puritan tradition, brought society's rewards. He was branded as lazy because he enjoyed reading and contemplation. He read and reread the Bible and a coverless copy of a history of Greece. He traced his later appreciation for the Greek language and literature to the tattered book with which he spent so many boyhood hours. Marc Darling admitted he was a "dull boy" and that he failed to "wake up" until he was about fifteen years old.

As a young man, he hired out in a succession of jobs, doing chores during the winter and working in a cider mill at least part of one summer. In September 1861 - just a few months after the outbreak of the Civil War-he attended Randolph Academy with three friends. The four lived and cooked for themselves in a room over a store. Marc Darling had been bitten by the desire to learn.

In September 1862 he enlisted with his brother DeLoss for three years, or the duration of the war, in Company $\mathrm{K}$ of the 154th New York Volunteers. Marc fought at Chancellorsville, 
was captured and escaped, and retreated with the Union Army. DeLoss Darling was captured at Gettysburg July 1, 1863, while Marc was hospitalized in Philadelphia with typhoid fever. DeLoss died at Annapolis January 16, 1865.

During the winter of 1863-64 Marc studied the "School of Soldier" textbook, passed the Army officer examination, and was recommended for a major's commission in a Negro regiment, which he declined. He later joined the forced march to the relief of Knoxville and took part in Sherman's march to the sea. At Pumpkinvine Creek he became a company commander because all the officers were sick or absent, and he conversed with General Sherman under fire on the skirmish line.

Marcellus Darling harbored little respect for politicians. Following Lee's surrender at Appomattox, Darling and his Union comrades camped at Raleigh, celebrated with returning Confederate soldiers, and recounted with them the campaigns of four bloody years. "They were fully happy as were we over the results, for the common people, soldiers, were never anxious for war," he observed, "except as the politicians and agitators roused them with appeals false and full of lies."

In August 1865 Marc Darling went to the Michigan farm home of his brother John at Albion. He worked on John's farm and that fall he began the preparatory course at Albion College. He lived at the farm, which was about three miles from the school. In 1870, five years after he began his studies there, Marc graduated from Albion. That fall at the age of 26, he became superintendent of city schools at Grand Haven, Michigan, at an annual salary of $\$ 1,200$. The following summer he was elected professor of Greek at Albion College and returned to his alma mater at about half his superintendent's pay $-\$ 700$ per year.

\footnotetext{
ChristMas DAY, 1871, Marcellus Darling was married to Clara R. Woolson at Mount Pleasant, Iowa. Clara, also a graduate of Albion College, and Marc had met at the school. The couple returned to Albion, where their first son, Frank, was born ten months later. In 1874, after three years of teaching at Albion, Marc Darling took his family to Ann Arbor, where he
} 


\section{J. N. "Ding" Darling}

earned the A.M. degree in philosophy in 1875 . He then went to Forestville in his native New York as the principal of Regents Academy, again at an annual salary of $\$ 1,200$.

Politics again entered Darling's life and brought it to an abrupt turning point. After school had closed for the academic year and everything was seemingly settled, he received a note from the secretary of the school board informing him that a new man had been elected to take his place. "Politics in the School Board did it," Darling exclaimed, and he decided to leave teaching. He later wrote, "It was then I resolved, under a sense of duty, to preach the gospel." In the months before Jay Darling was born, Marcellus Darling was groping his way through a tunnel of religious doubt. He emerged "with a tried faith in the simple, essential and practical truths of the gospel."2

Darling's religion was pragmatic, and his philosophy included respect for nineteenth-century self-reliance. In 1905 he wrote:

Since the time of [Sir Francis] Bacon we have learned to apply the inductive method with very fruitful results to nearly everything else, except the Bible. We can no longer delay. We must have a doctrine of inspiration which corresponds to the facts. ... We praise charity, and invoke heaven for a larger supply. But it is a fact to which we are beginning to wake, that this very charity without eyes is the cause of the social parasite. ${ }^{3}$

Shortly after the new minister and his wife were settled in Norwood, Jay Darling was born. Despite the rude conditions, that year was one of the happiest of Marc Darling's life. ${ }^{4}$ Jay's one distinct memory of Norwood led him to judge that the community, even in its period of greatest prosperity and activity, was never an Eldorado. His mind's eye recalled the inside of the Darlings' woodshed hung with spareribs, which constituted the chief contribution to his father's salary from members of the congregation. Marc Darling received provisions in abundance,

${ }^{2}$ The account of the early life of Marc Darling, before he entered the ministry, is from the privately published work by Marcellus Warner Darling, Marcellus Warner Darling, 1844-1913 (Glencoe, Ill.: Clara W. Darling [1913]), 723.

${ }^{3}$ Marcellus Warner Darling, Fusing Truth into Life (Glencoe, Ill.: Marcellus W. Darling, 1906).

${ }^{4}$ M. W. Darling, Darling, 23. 
although he often had to trade eggs for flour at the grocery store. ${ }^{5}$

The Reverend Marcellus Darling and his family were transferred from Norwood in the fall of 1877, when Jay was only about a year old. The Darlings were sent to Cambria in the southern part of Michigan, where they remained for two years at an annual salary of $\$ 800$. In May 1879 Darling accepted a call to become pastor of the First Congregational Church in Elkhart, Indiana. He went to Elkhart at a salary of $\$ 800$, but his compensation had grown to $\$ 1,200$ when in 1886 he moved on to the First Congregational Church of Sioux City, Iowa. ${ }^{6}$

While in Elkhart the Darlings became acquainted with a man who had a hand in shaping the life of Jay Darling and who launched the versatile business career of Jay's brother, Frank. Lamarcus Thompson sent an illustrated "Pat and Mike" card to Marc Darling from England, where he had gone to build Europe's first roller coaster. ${ }^{7}$ Jay was intrigued by the drawing on the card and tried to imitate it. He soon made a habit of carrying a pad of paper and a pencil and sketching several objects each day, even though the Puritan ethic was still the credo of the family. Drawing was considered a waste of time in the Darling home. "To my father and mother artists who drew pictures were classed with wicked playing cards, dancing and rum," Darling reported. ${ }^{8}$

Most of Jay's recollections of his youth, however, were drawn from his days in Sioux City, when that community was a robust and roughshod Missouri River town and a gateway to the unspoiled prairies of Nebraska and South Dakota. An energetic youngster of ten when he arrived in Sioux City, Jay grew to manhood there, left for college from there, and returned there to begin his newspaper career.

His youthful experiences in communities on the edge of untrammeled wilderness contributed to Darling's zealous commitment to conservation. Even though he left Michigan as a very

5J. N. Darling to Russell A. Runnells, September 18, 1942, DP.

'M. W. Darling, Darling, 23-24.

'Saturday Evening Post, October 19, 1940, 34.

${ }^{8} \mathrm{~J}$. N. Darling to Lynn Bogue Hunt, January 27, 1944, DP. 


\section{J. N. "Ding" Darling}

young child, he could recall Indians coming to the back door with duck eggs for sale and had been told of their throwing several wild ducks into the bargain because the fowl were so plentiful. ${ }^{9}$

If ducks were plentiful, money was not. Darling was scolded much of his young life for making spots on the family tablecloth. "When I was a,youngster and Mother did our laundry," he wrote, "I had to cover every spot I made on the tablecloth with a coin; and coins were not easily come by in those days, but even that didn't break me of the very bad habit." Even so, the family fared well enough at a time when five cents worth of liver from the local market, with baked potatoes and Hubbard squash, was enough for a Sunday dinner for a Methodist minister's family of four. ${ }^{10}$

Jay Darling thrived in the spacious fields of high grass through which he and his brother Frank roamed, whether afoot or astride their spirited Indian ponies. He spent many summer nights on the prairie or along the banks of the Missouri River or the Big Sioux River, listening to the voice of the puma-or panther, as it was called in northwestern Iowa. He intended in those days not to let any marsh, lake, or pothole escape his attention. He came to know eastern South Dakota as well as most youngsters know their backyards; and his communion with South Dakota's pristine bounty - its head-high grass and abundant underground water-provided the ingredients of the "pleasantest recollections" of his long and eventful life. ${ }^{11}$

One of Jay's Sioux City neighbors was Max McGraw, who later headed the huge McGraw-Edison Electric Company. Jay, the preacher's son, was obliged to take an active part in the church choir and to play the organ. McGraw was active in a supporting role. "I little thought," he later wrote, "when I was a boy pumping the organ in the church of Ding's father that either of us would see the changes in this world of ours which Ding so

${ }^{9} J$. N. Darling to John A. Dehner, January 26, 1959, DP.

${ }^{10} \mathrm{~J}$. N. Darling to Dr. and Mrs. Clarence Cottam, June 17, 1960, DP; J. N . Darling to Mrs. Addison Parker, November 21, 1959, DP.

${ }^{11}$ J. N. Darling to Dr. Stanley Young, January 13, 1956, DP; J. N. Darling to Paul Errington, January 4, 1958, DP; J. N. Darling to F. Fraser Darling, May 13, 1959, DP; J. N. Darling to J. Clark Salyer II, December 7, 1960, DP. 
meticulously" recorded in his cartoons. ${ }^{12}$ The lives of the two boys converged on the banks of the Missouri, and the lives of the two men later converged in common conservation interests.

During summers Jay hired out to his Uncle John in Albion, Michigan, where he mowed marsh hay with a scythe and cradled the wheat in the corners of the south forty that the McCormick reaper could not reach. The work was strenuous but the yield was bountiful. The small but rich farm was a paradise to the teenaged Darling. A clear stream ran across one corner, and a small stand of native timber stood on virgin soil. The water was full of fish, migratory waterfowl nested beside the stream, and the timber was alive with songbirds. He fished in the same creek and hunted on the same millpond and timbered shores near Albion as did Lynn Bogue Hunt, who became famous as a wildlife artist. ${ }^{13}$

Jay Darling's first lesson in conservation came literally at the hand of his Uncle John. The youth had shot a wood duck in midnesting season, and John had blistered his nephew's rear. In the proper season, however, ducks were so abundant that Jay recalled his uncle saying, "Now, I will do your milking for you; you go down and get a mess of ducks for dinner."14

In other summers, after he was old enough to be "turned loose," he rode out of Sioux City, across the Big Sioux, and into South Dakota to herd cattle for anyone who would hire him.

Those were the days when the Golden Plover came in great flocks and moved across South Dakota and, from early spring until the Prairie Chicken sought cover in the fall along the thickets bordering the creek and marshes, my mind was filled with pictures which have never been erased. It was the disappearance of all that wonderful endowment of wildlife which stirred the first instincts I can remember of conservation. ${ }^{15}$

When the Darlings first moved to Iowa, flat-bottom sternwheelers plied the waters of the Missouri River between Sioux

${ }_{12}$ Max McGraw, mimeo insert, 1960, DP.

${ }^{13}$ J. N. Darling to Philip A. DuMont, September 16, 1960, DP.

${ }^{14}$ Darling to Hunt, January 27, 1944, DP; Post, September 21, 1935, 14-15.

${ }^{15}$ Darling to Errington, January 4, 1958, DP. 


\section{J. N. "Ding" Darling}

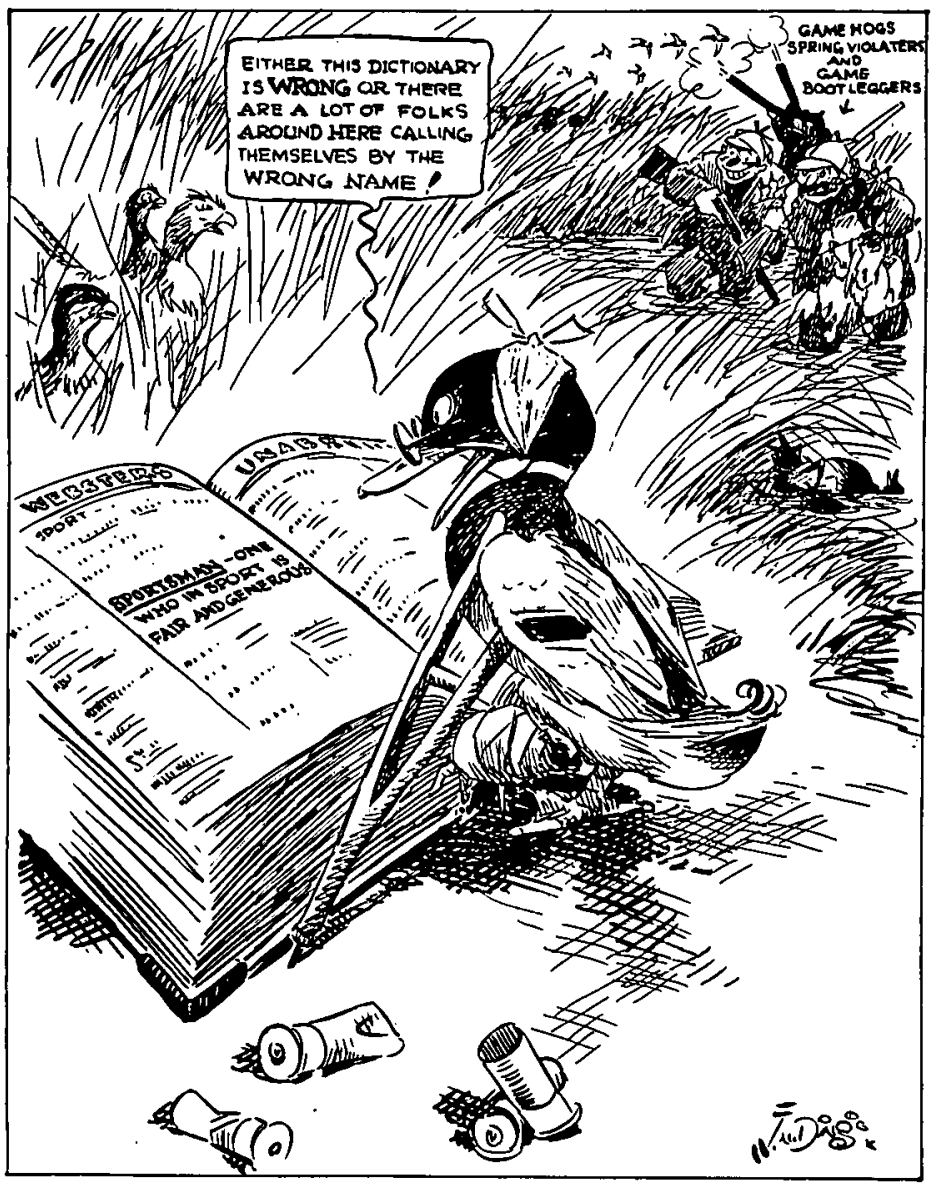

Wby Call Them Sportsmen?

"Why Call Them Sportsmen?" One of Darling's most popular conservation cartoons, this one spoke up for the defenseless duck. As Chief of the Biological Survey, Darling was tough on game law violators and earned his reputation as "the best friend a duck ever had." This cartoon appeared in 1937. 
City and Kansas City, even though "they spent most of their time stuck on sand bars." About 1885 the last such riverboat ran onto a snag, ruptured its hull, and sank. As a boy, Jay saw the stern-wheelers loaded with bales of raw buffalo hides destined for the St. Louis market. ${ }^{16}$

Marcellus Darling was not a wealthy man, but he believed deeply in the advantages of education. In 1895, when Jay was nineteen years old, the Darling family toured Europe. The excursion was made on $\$ 400$ per person, for which every Darling had "worked, saved, read evenings and planned for years in advance." In 1888 Jay Darling earned a four-by-five wood box camera by selling ten subscriptions to Youth's Companion and scratching up $\$ 5$ in cash, and he had become proficient as a photographer. His was the first amateur camera in Sioux City, and with it he took pictures of his inseparable companion Jay Dundass, his family, friends, and the neighborhood around 1423 Nebraska Street. The same fourteen-inch-long camera accompanied the Darlings on their European tour, "greatly to the discomfort of all-particularly the endless customs officers." The elder Darling also set aside resources and the time for summer vacations. Jay Darling recalled the Storm Lake, Iowa, resort of the early 1890s and Mae Beggs. The Reverend Marcellus Darling and Doctor Beggs brought their children to Storm Lake and, whether by accident or design, kindled Jay's first romance. "Mae Beggs," he later wrote, "blond, beautiful and dumb - who furnished all the dreams and aspirations of my callow days." 17

D ARLING ALSO retained more sobering recollections. He . remembered the day Sioux Citians gathered on the riverfront to watch the city of Covington, Nebraska, on the opposite bank of the Missouri, crumble into the river. The Missouri River had

${ }^{16} \mathrm{~J}$. N. Darling to M. O. Steen, July 28, 1960, DP; Darling to Young, January 13, 1956, DP; J. N. Darling to Juanita Lines, February 9, 1959, DP.

${ }^{17}$ Handwritten notes, Scrapbook 1, DP. 


\section{J. N. "Ding" Darling}

undercut the community's buildings and destroyed them "while the people skedaddled to the hills."18

Perhaps even more clearly, Darling remembered the shattering experience of returning to his uncle's farm as the family representative to John's funeral. "It was the first time I had seen my youthful paradise since I was about fifteen years old and it seemed as if the farm had died with Uncle John," Darling wrote. He strolled down the lane to the pasture and the woods. The topsoil of the grain field had been stripped away. The timber had been cut. The river was reduced to a muddy trickle unfit for game fish. The pasture, bare of grass, was scarred and slashed by erosion and no longer of any use. A solitary crow rose from the barnyard and slowly flapped out of sight-the only sign of wildlife left on the place. The well had gone dry. The orchard was a tangle of dead limbs and tree stumps. There was nothing left worth cultivating where Darling had once plowed eight inches of black loam and reaped sixty bushels of wheat per acre. "This was my first conscious realization of what could happen to clear running streams, what could happen to bird life and human life when the common laws of Mother Nature were disregarded," he later wrote. ${ }^{19}$

Sioux City and its surroundings were still new, and humankind had not sullied them. The rivers were deep, and game of all kinds was abundant. "Life," Darling recalled, "was rich and easy. Everyone hunted and everyone fished and everyone helped himself liberally to the riches which Nature provided." But by the time Darling himself was a father, waves of settlers had plowed up the prairies, cut the timber bordering the creeks and rivers, harvested the game, and turned their cattle loose to strip the protective grasses from the land. The unconcerned pioneers had spoiled their eastern nests and pushed westward to abuse newer and greener pastures.

Darling brooded at the prospect of seeing the saga of his Uncle John's farm repeated. He read the similar concerns expressed much earlier by Benjamin Franklin, Thomas Jefferson, Audubon, and Samuel Adams. Theodore Roosevelt and Gifford Pin-

${ }^{18}$ Darling to Steen, August 4, 1960, DP.

${ }^{19}$ Darling to Lines, February 9, 1959, DP. 
chot later fired his determination with their courageous endorsement of conservation principles and their condemnation of those who violated the tenets of good stewardship. The minister's son was so inspired that he "spoke up in prayer meeting" for restraint, even though most of the parishioners were convinced "that Uncle Sam was rich enough to give us all a farm, and let us get ours while the getting is good."20

"If I could put together all the virgin landscapes which I knew in my youth and show what has happened to them in one generation it would be the best object lesson in conservation that could be printed," Darling claimed. He later wrote, "All it takes to be a conservationist is to have been awake and a witness to what has happened to all our continental forests, soils, waters, minerals and wildlife in the last fifty or seventy-five years and he'll be a conservationist from fright! That's me."21

Jay Darling, a child of the centennial, had seen that just one generation of indifference, neglect, and needless abuse of natural riches could shortchange every generation to follow. He saw the results of despoilation. He was a witness to waste.

${ }^{20}$ Ibid.

${ }^{21}$ Darling to Hunt, January 27, 1944, DP; J. N. Darling to Charles H. Callison, July 1, 1947, DP. 
Copyright of Annals of Iowa is the property of State of Iowa, by \& through the State Historical Society of Iowa and its content may not be copied or emailed to multiple sites or posted to a listserv without the copyright holder's express written permission. However, users may print, download, or email articles for individual use. 